\section{-}

Business \& Social Science IJRBS

\section{Research in Business and Social Science}

IJRBS Vol 6 No 5, Special Issue, ISSN: 2147-4478

Contents available at www.ssbfnet.com/ojs

http://dx.doi.org/10.20525/ijrbs.v6i5.765

\title{
Minimizing Tax Avoidance by Using Conservatism Accounting Through Book Tax Differences (Case Study in Indonesia)
}

\section{Heni Purwantini}

Institute of Economic Science of Jaya Negara Malang, Indonesia 0341-491154

\begin{abstract}
The research's first purpose is to analyze directly conservatism accounting influence towards book tax differences and tax avoidance. The second purpose is to analyse indirect influence towards tax avoidance through book tax differences. The research is conducted to companies enlisted in Indonesian Stock Exchange and belongs to LQ45 during 2013 to 2015. The number of companies sample taken by purposive sampling is 23 corporations, therefore total observation is 69 observations. The acquired data analysed by path analysis. This research conclude that conservatism accounting practice significantly influence book tax difference practice but did not influence tax avoidance. Conservatism accounting practice is also having no influence towards tax avoidance committed by book tax differences. This book tax difference is only significantly influential to commit tax avoidance. This research can contribute in taxation field as input in tax planning formulation.
\end{abstract}

Key words: Book Tax Differences, Conservatism Accounting, Corporations, Path Analysis, Indonesian Stock Exchange, Tax Avoidance

JEL classification: H26, M41, G30

\section{Introduction}

Tax avoidance is one of tax collection problems that cause state's income to decrease. Tax avoidance is usually committed by using exception and cuts permitted in the regulation or unregulated things in tax regulation. Perspective on tax avoidance is different in each company, depends on the interest of related stakeholders. According to Dyreng, Hanlon, and Maydew (2010), individual implementer is the one who hold significant role in determining the level of company's tax avoidance. The government in this case, Directorate General of Taxes, can not punish the company because the nature of tax avoidance itself does not violate the rule. Tax 
avoidance does not belong in the category of tax laws because the taxpayer's attempt to minimize or avoid the tax expense is committed by various ways made possible by tax laws. According to Finnerty, Merks, Petriccione, and Russo (2007), the ways that can be done for such things are: first, moving the tax subjects and or objects to countries that implement special treatment on tax or tax haven country on substantive tax planning. Second, tax avoidance attempt can be done through formal tax planning that give the taxpayer lowest tax expense. The third, by using anti-avoidance requirements towards transfer pricing, thin capitalization, treaty shopping, and controlled foreign corporation (specific anti avoidance rule), and transaction without business substance (general anti avoidance rule). In recent years, the tax authorites tried as hard as they can, not only to enforce clear boundaries between tax avoidance and tax evasion in tax planning, but also to prevent taxpayer from entering obscurity caused by tax laws (Bovi, 2005). With so many negative impacts caused by tax avoidance, research is needed to minimize the occurance, by investigating variables related to tax avoidance.

Businessman financial report making is certainly unseparated from general policies, i.e., financial accounting standard. Bookkeeping recording in accordance with accounting is using basic principle of conservatism. This conservatism is an approach of financial reporting to investigate and measure assets and profits which is conducted with full caution due to economic and business activity's uncertainty. The implication of this principle's implementation is accounting model choice would be oriented to the method that report lower profits and assets or higher loan (Watts, 2003). This can cause conservatism principle implemented indirectly influence financial report's accuracy, where the compiled financial report will further be made as a foundation in decision and policy making for company's management in related matters. According to Basu et al., (1997) and Watts (2003), conservatism is accounting practice that decrease profits (and lower net assets) when faced with bad news but does not increase profits (and increase net assets) when faced with good news.

Information source for financial information users-investor, creditor, manager, and others, require responsible financial report. The developing issue related with tax regulation analysis is book tax differences. Book tax difference is the difference between taxable income based on taxation and taxable income based on accounting standard. Taxation regulation and accounting have different purpose and results in different reports, the difference on this financial report occur in almost all countries. This phenomenon causes tax avoidance that possibly committed by tax payer for their tax planning. Besides, this book tax differences is often used as factor in research due to it's usability to track profit management and tax activity closely related with tax avoidance (Lee, Vetter, \& Williams, 2015).

The explaination above justified the selection of conservatism accounting and boox tax differences as research variables on minimizing tax avoidance. Therefore, this research discusses minimization of tax avoidance by using conservatism accounting by book tax differences. This research simultaneously uses tax avoidance, conservatism accounting and book tax differences. This simultaneousness has never been applied in previous researches. This research's hypotheses are:

Hypothesis 1 : There is influence of conservatism accounting towards book tax differences.

Hypothesis 2 : There is influence of conservatism accounting towards tax avoidance.

Hypothesis 3 : There is influence of book tax differences towards tax avoidance.

Hypothesis 4 : There is influence of conservatism accounting towards tax avoidance to book tax differences. 


\section{Literature Review}

Tax avoidance is an attempt to alleviate taxes without violationg the laws. Hanlon and Heitzman (2010) stated that there is no universally accepted definition of tax avoidance, everyone or every researcher has different understanding. Tax avoidance defined largely as an attempt for tax deduction and reflected all transactions influencing company's explicit tax debts. Tax payer always wants small tax payment. Therefore, many tax payers commit tax avoidance both legally and illegally. The term tax avoidance means the legal one, meanwhile the illegal one is tax evasion. According to researches by Dyreng, Hanlon, and Maydew (2010) and Hanlon and Heitzman (2010), tax avoidance is any activity that affect tax payer, both activity permitted by tax or special activity for tax deduction. The legal tax avoidance usually inseparable with the illegal tax evasion because most of the behaviors around the transaction is technically legal. The transaction legality of tax avoidance often set not according to facts. Tax avoidance usually exploits tax laws weakness and not violating taxation laws.

Conservatism accounting stated that this practice generates profits with higher quality because it prevents the company to exaggerate earnings and present profits and assets which are not overstated. Conservatism accounting in company applied in different levels. One of the very defining factor towards conservatism level in company financial report is management and company's internal parties commitment in providing transparent, accurate, and not misleading information towards the investors (Watts, 2003).

Book tax differences are part of taxation level unobserved from tax planning. Based on previous researchers' intuition, the difference between profit values based on company book (commercial profit) with profits based on tax calculation (fiscal profit), called as book-tax difference (BTD). This Book tax differences reflects company's tax avoidance. This is committed by attempting to report high book profit for the interest of stockholders, while in the other hand implementing strategy to acquire low tax. According to Wilson (2009) book-tax differences can reflect tax avoidance in long term and short-term strategy. Company's financial report is an importantlyneeded information source for various parties, investors, creditors, manager, and for taxation. Every measurement from company's financial report has deficiency, but useful for researcher's estimation (Hanlon \& Heitzman, 2010). According to Abdul Wahab and Holland (2015), academic researchers and activists use the difference between financial income and expected tax income as the definition of book tax differences. Jackson (2015), in his research divide total book-tax differences into two categories, i.e., permanent and temporary book-tax differences. The research result revealed that temporary book-tax differences can predict future changes in pre-tax earnings. Meanwhile permanent book-tax differences permanent can predict future changes in term of tax costs.

Previous research related with this research is Givoly and Hayn's (2002) that used effective tax rate to see the influence of book tax differences towards tax avoidance, which is showing influencing results. Watts (2003) and George A. Plesko (2004) also showed that the implementation of conservatism accounting to company towards tax avoidance is not influential. Blaylock, Shevlin, and Wilson (2012) also have researched all kinds of company enlisted in US Stock Exchange by testing the role of book tax differences towards tax avoidance. Book tax differences in this research are tested and resulting in conclusion showing that temporary book tax differences can give additional information on the amount of accruals. Hanlon and Heitzman (2010) research results showed an influence of book tax differences towards tax avoidance. Meanwhile Jackson (2009) conducted research on the influence of book tax differences towards profit accumulation which it's result is negatively influential, in other words the implementation of book tax differences reach bigger differences with accrual booking therefore earning persistence 
grew smaller. Guenther et al. (2014), in their research saw that effective tax rate affect book tax differences and influence tax avoidance. Last, Annuar, Salihu, and Obid (2014) researched corporate tax avoidance. Corporate ownership structure also influences tax avoidance.

\section{Research and Methodology}

This is a quantitative research which in it's processing was using SPPS 18.0 for Windows Statistics Program to see the inter-variable influence researched and to test the hypothesis. The study population consisted of 71 corporations ready to go public, enlisted in LQ45 list in three periods (2013-2015). Meanwhile corporation samples taken by purposive sampling are 23 corporations with 69 years of observations. Those corporation samples have fulfilled certain criteria as following:

1. Published audited annual report;

2. Belong to the category of go public corporations enlisted in LQ45 index in Indonesian Stock Exchange in 2013-2015 consecutively;

3. Having data required for the research

Based on previous researches in accordance with research roadmap, the following figure 1 shows the research plan.

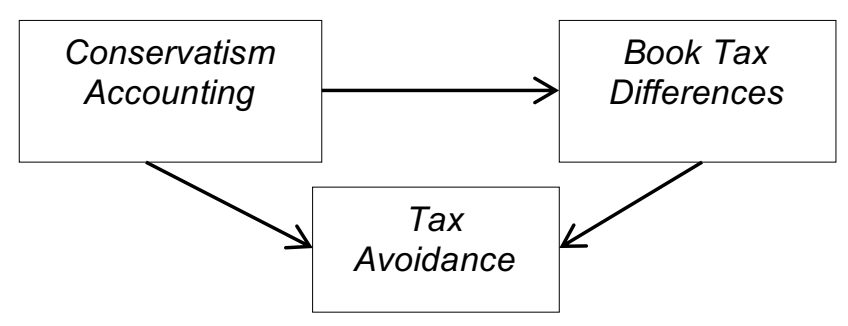

Figure 1. Research Plan

\section{Tax Avoidance}

Tax avoidance defined largely as explicit tax deduction and reflects all transactions influential to company's explicit tax debt. The equation to measure tax avoidance is:

$$
\text { GAAP ETR }=\frac{\text { Income Tax Expense }}{\text { Profit Before } \text { Tax }} \ldots . . .
$$

\section{Conservatism Accounting}

Conservatism accounting is reaction that tends to orient towards prudent reaction in admitting and measuring income and assets. Conservatism is measured using accrual. If accrual is negative, then the profit is categorized as conservative, since the profit is lower than acquired cash flow (Givoly \& Hayn, 2002).

$$
\text { KON_ACC }=\frac{N I-C F}{R T A}
$$

KON_ACC : The level of conservatism accounting

$\mathrm{NI}$

: Profit before extraordinary items

CF

: Operation cash flow added with depreciation expenses 


\section{Book Tax Differences}

Book tax differences (BTD) is the difference between the amount of accounting profit amount with profits measured in accordance to taxation rules. According to Jackson (2009), to calculate book tax by decreasing fiscal net profits with commercial net profits, we can use following approach:

$$
\text { BTD }=\frac{\text { Profit Before Tax } \text {-Profit After Tax }}{\text { Average Assets }}
$$

\section{Findings}

This research use path analysis to know the causality connection that shows direct and indirect influences between independent variable with dependent variable. This Path analysis according to J. L. Jackson, Dezee, Douglas, \& Shimeall (2005); Wuensch (2016) can be used to determine nonexperimental data with many variations or variable suitable with certain problem. This thing caused path analysis often called with causal modelling. This research used three variables, i.e., conservatism accounting (KON_ACC), book tax differences (BTD), tax avoidance (GAAP ETR). By using path analysis, the relation between those variables, direct or indirect mediated or mediated by another variable can be known (Shevlin, Urcan \& Vasvari, 2013).

\section{Descriptive Test Result}

Table 1: Descriptive Test Result

\begin{tabular}{|l|l|l|l|l|}
\hline Variables & Mean & Std deviation & Minimum & Maximum \\
\hline Tax Avoidance & 0,2266 & 0,16090 & $-0,96$ & 0,55 \\
\hline Conservatism accounting & $-0,0312$ & 0,14439 & $-0,32$ & 1,03 \\
\hline Book Tax differences & 0,0205 & 0,11298 & $-0,99$ & 0,14 \\
\hline
\end{tabular}

Source: 2017 processed secondary data

Table 1 shows that the average score of tax avoidance in this research is 0.2266 or $22.66 \%$ (st.dev $=0.16090)$. Average score of conservatism accounting is -0.312 or as much as $-(31.2) \%$ (st.dev $=0.14439$ ). Average score of_book tax differences is 0.0205 (st.dev=0.11298). 


\section{Normality Test and Heteroscedasticity Test Result}

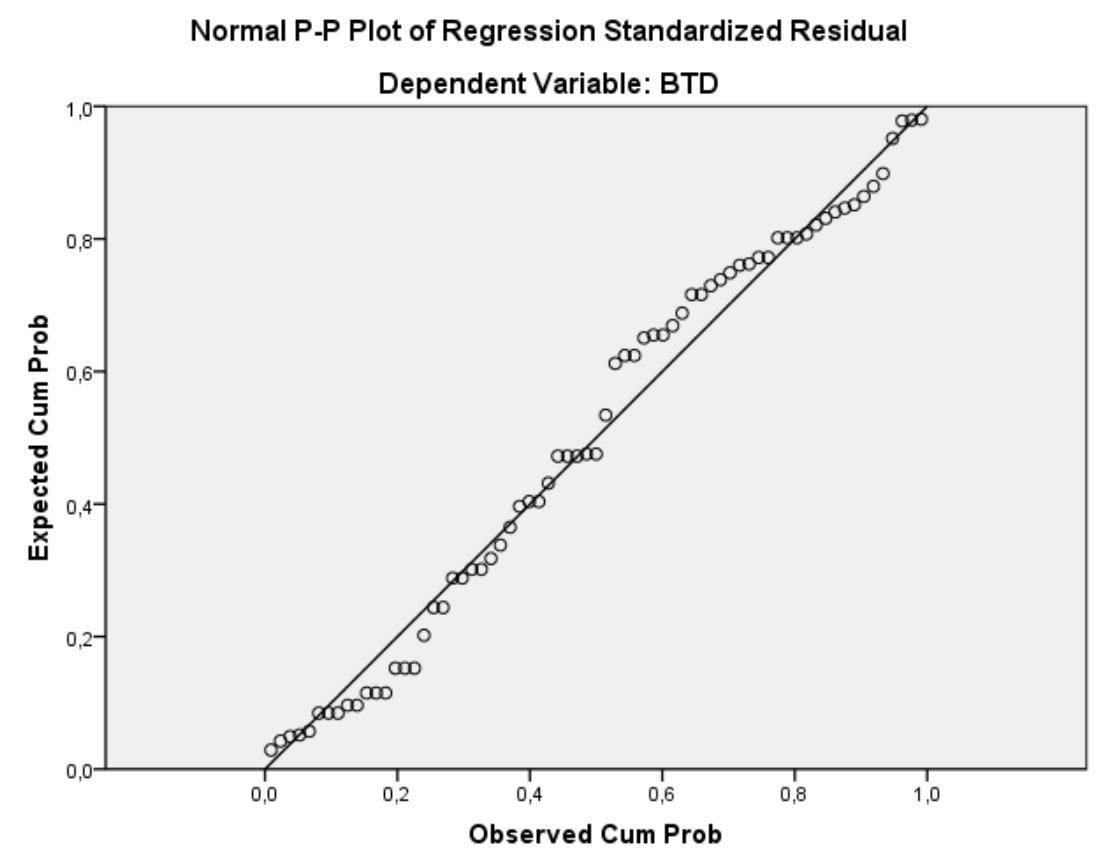

Figure 2. Normality Test Figure Model 1

Figure 2. Shows that residual spots spread around diagonal line, therefore the residual resulted from first model of BTD $=\rho_{1} C A+\varepsilon_{1}$ and second model i.e., $T A=\rho_{2} C A+\rho_{3} B T D+\varepsilon_{2}$ considered as normal distribution.

Normal P-P Plot of Regression Standardized Residual

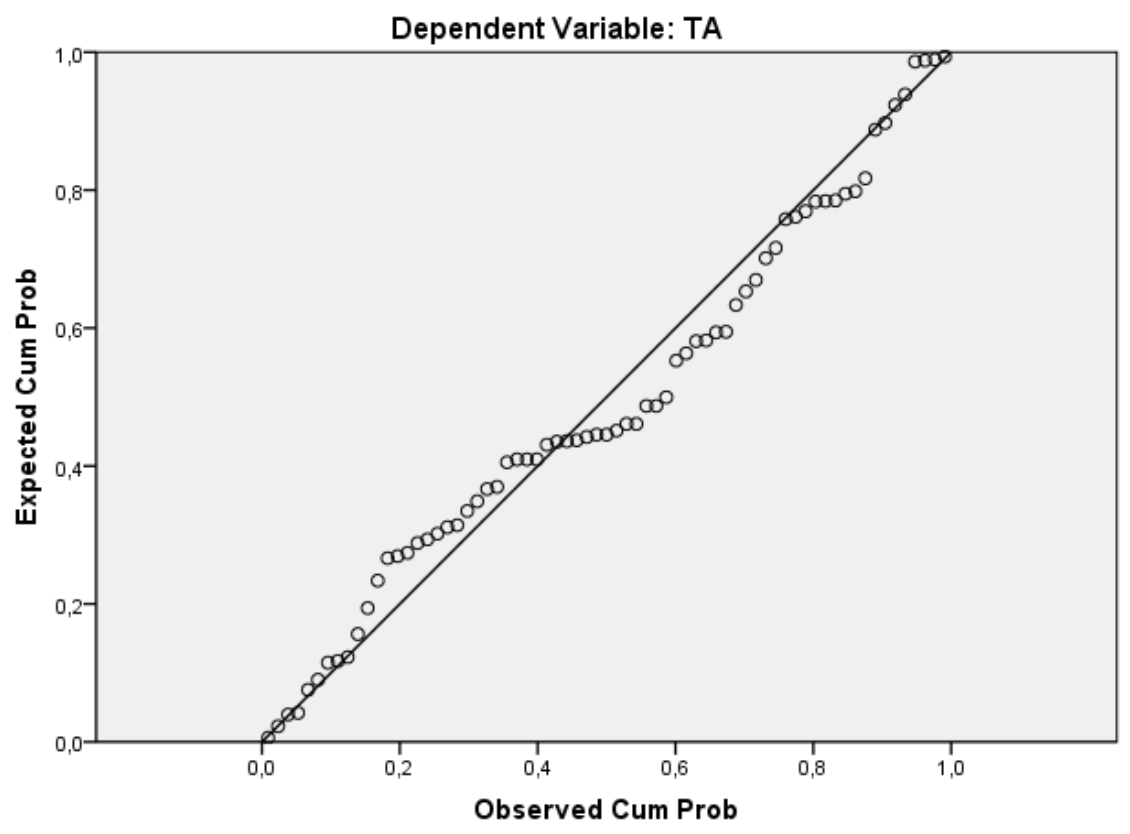

Figure 3. Normality Test Figure - Model 2 
Test result in figure 3 shows residual spots spread randomly, therefore residual resulted from first model of BTD $=\rho_{1} C A+\varepsilon_{1}$ and second model, i.e., $T A=\rho_{2} C A+\rho_{3} B T D+\varepsilon_{2}$ can be considered as no heteroscedasticity.

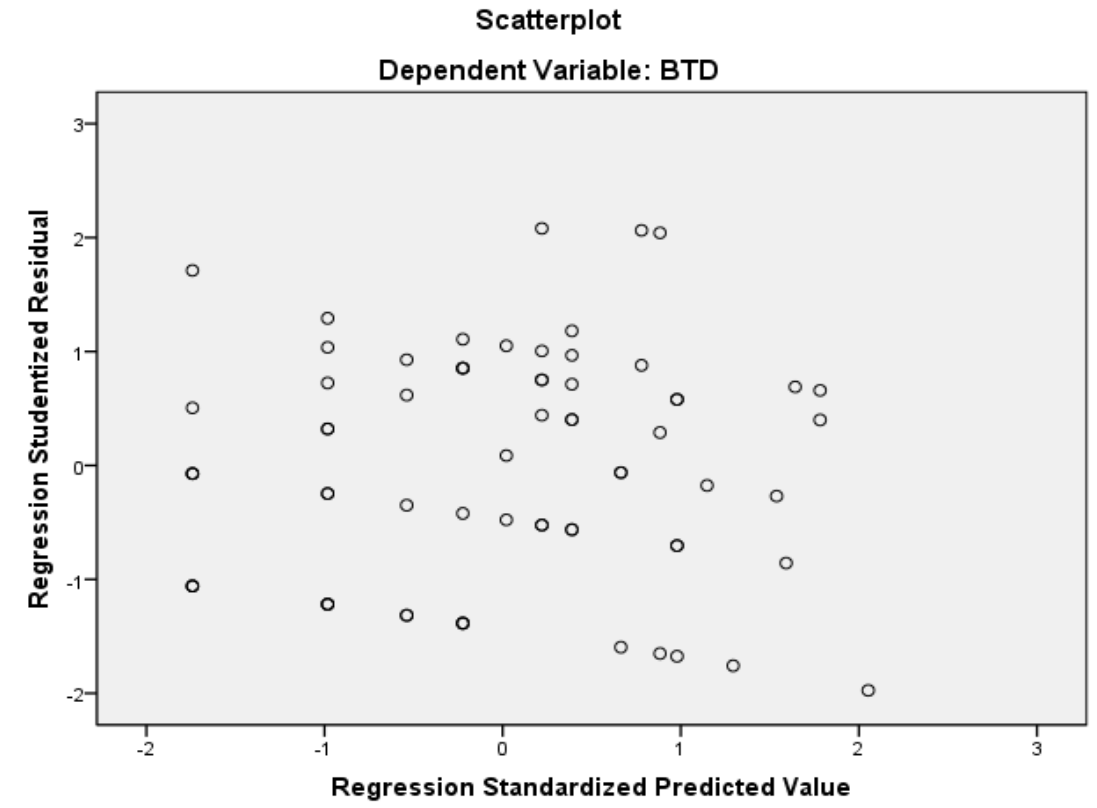

Figure 4. Heteroscedasticity Test - Model 1

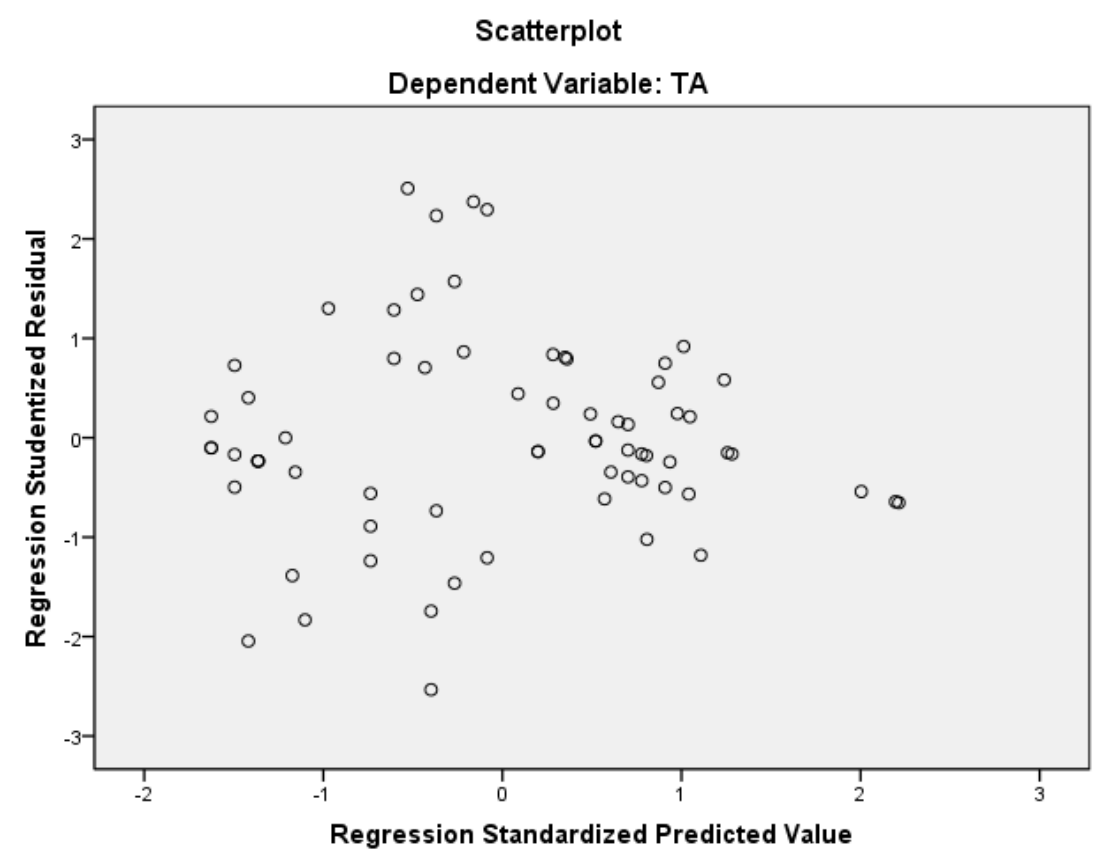

Figure 5. Heteroscedasticity Test - Model 2 


\section{Auto-Correlation Test Result}

Table 2: Auto-Correlation Result

\begin{tabular}{|l|l|}
\hline Models & Durbin Watson's \\
\hline Model 1 & 1.656 \\
\hline Model 2 & 1.864 \\
\hline
\end{tabular}

Source: 2017 processed secondary data

Based on the information from table 2, model 1 with the equation BTD $=\rho_{1} C A+\varepsilon_{1}$ resulted in Durbin Watson value of 1.656, DW value is between $\mathrm{dU}-(4-\mathrm{dU})$. This means that equation on model 1 has no auto-correlation. Meanwhile model 2 with equation TA $=\rho_{2} C A+\rho_{3} B T D+\varepsilon_{2}$ results in Durbin Watson value of 1.864, DW values located in dU - (4-dU) means that model 2 has no auto-correlation. These two research models are free from auto-correlation.

\section{Path Analysis}

According to J. L. Jackson, Dezee, Douglas, and Shimeall (2005) in path analysis, exogenous and endogenous variables stated to make it easier in differing which variable depended on other variable and which one is not in particular condition. This exogenous variable is independent variable meanwhile endogenous variable is dependent variable.

Table 3: Path Analysis Result

\begin{tabular}{|l|l|l|l|l|l|}
\hline Exogenous Variable & $\begin{array}{l}\text { Endogenous } \\
\text { Variable }\end{array}$ & $\begin{array}{l}\text { Estimation } \\
\text { Coefficien } \\
\mathrm{t}\end{array}$ & $\begin{array}{l}\mathrm{t} \text { - } \\
\text { statistic }\end{array}$ & $\begin{array}{l}\mathrm{p}- \\
\text { value }\end{array}$ & $\begin{array}{l}\text { Descriptio } \\
\mathrm{n}\end{array}$ \\
\hline $\begin{array}{l}\text { Conservatism accounting } \\
\text { (CA) }\end{array}$ & $\begin{array}{l}\text { Book tax } \\
\text { differences (BTD) }\end{array}$ & 0,225 & 1,892 & 0,063 & $\begin{array}{l}\text { Significan } \\
\mathrm{t}\end{array}$ \\
\hline Book tax differences (BTD) & $\begin{array}{l}\text { Tax avoidance } \\
\text { (TA) }\end{array}$ & 0,429 & 3,805 & 0,00 & $\begin{array}{l}\text { Significan } \\
\mathrm{t}\end{array}$ \\
\hline $\begin{array}{l}\text { Conservatism accounting } \\
\text { (CA) }\end{array}$ & $\begin{array}{l}\text { Tax avoidance } \\
\text { (TA) }\end{array}$ & 0,078 & 0,693 & 0,491 & $\begin{array}{l}\text { Not } \\
\text { significant }\end{array}$ \\
\hline
\end{tabular}

Source: 2017 processed secondary data

Research result in table 3 shows that book tax differences (BTD) can be explained significantly by exogenous variable of conservatism accounting (CA). Tax avoidance (TA) endogenous variable can be explained significantly by book tax differences exogenous variable, but cannot be explained significantly by conservatism accounting (CA) variable. Those path coefficients are hypothesis in this research and can be presented in two equation models. 


\section{Model Testing}

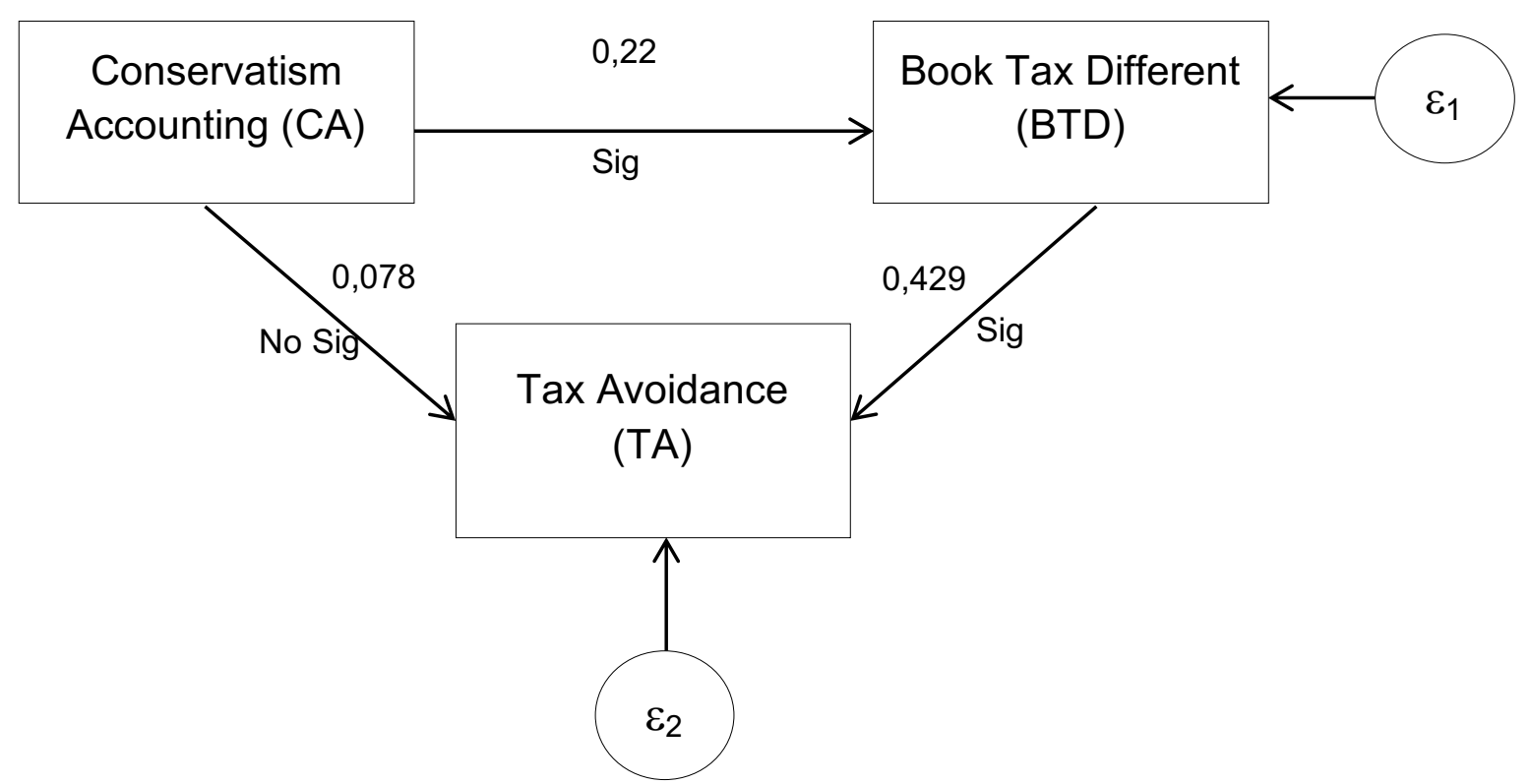

Figure 6. Path Analysis Result

Based on Figure 6, the two equation models can be written as following:

Model 1: $\mathrm{BTD}=0,225 \mathrm{CA}+\varepsilon_{1}$

Model 2: TA $=0,078 \mathrm{CA}+0,429 \mathrm{BTD}+\varepsilon_{2}$

Based on path analysis results and models made, it can be seen that:

1. The coefficient of path relation of conservatism accounting variable with book tax differences variable is 0.225 and is significant at 0.1 .

2. The coefficient of path relation of conservatism accounting variable with tax avoidance variable is 0.078 and is insignificant at 0.1 .

3. Path coefficient of book tax differences variable with tax avoidance variable is 0,429 and is significant at 0,1

\section{Determination Coefficient Test Result}

Table 4: Determination Coefficient Test Result

\begin{tabular}{|l|l|}
\hline Description & $\mathrm{R}^{2}$ \\
\hline Model 1 & 0.051 \\
\hline Model 2 & 0.205 \\
\hline$R^{2} m=\sqrt{\frac{1}{1-R^{2}} 1 \sqrt[*]{1-R^{2} 2}}$ \\
$=1-\left\{\sqrt[1-0,051^{*} \sqrt{1-0,205}]{ }\right.$ \\
$=0.1314$ \\
\hline
\end{tabular}


Test result in table 4, shows that $\mathrm{R}^{2}=0.1314(13.14 \%)$, it means that Tax Avoidance can be explained by Conservatism Accounting and Book Tax Different are $13.14 \%$. This means that contribution of Conservatism Accounting and Book Tax Different variable towards Tax Avoidance is as much as $13.14 \%$. Meanwhile the rests are as much as $86.86 \%$ explained by another variable not included in the model.

\section{Inter-Variable Influence}

The research result of direct, indirect, and total influential testing result can be seen in table 5 , as following

Table 5: Direct, Indirect, and Total Influence

\begin{tabular}{|l|l|l|l|l|l|}
\hline $\begin{array}{l}\text { Exogenou } \\
\mathrm{s}\end{array}$ & $\begin{array}{l}\text { Endogenou } \\
\mathrm{s}\end{array}$ & $\begin{array}{l}\text { Mediatio } \\
\mathrm{n}\end{array}$ & Direct & Indirect & Total \\
\hline CA & BTD & - & 0,225 & & 0,225 \\
\hline CA & TA & BTD & 0,078 & $\begin{array}{l}0,078^{*} 0,429 \\
=0.033\end{array}$ & $\begin{array}{l}0,078 \\
0,033 \\
=0,114\end{array}$ \\
\hline BTD & TA & - & 0,429 & & 0,429 \\
\hline
\end{tabular}

Source: 2017 processed secondary data

\section{Direct Influence Result}

Based on the above table 5, CA direct influence coefficient towards BTD is as much as 0.225 , which means that CA positively influences BTD. CA direct influence coefficient towards TA as much as 0.078 which means CA positively influences TA. BTD coefficient towards TA is as much as 0.429 , which means BTD positively influences TA.

\section{Indirect Result}

Result shows that CA indirect influence coefficient towards TA through BTD is as much 0.033 .

\section{Total Influence Result}

Total CA influence coefficient towards BTD is as much as 0.225 , which means there is positive influence from CA towards BTD. BTD's total influence coefficient towards TA is as much as 0.429 and CA's total influence coefficient towards TA through BTD is as much as 0.114 . Although the CA's total influence results towards TA through BTD is smaller compared with each other's coefficient results, but it showed that there is still an influence from CA towards TA through BTD.

\section{Result and Discussion}

Hypothesis test result partially shows that conservatism accounting variable has significant influence towards book tax differences. This research supports Hanlon's (2005), which showed that the company has to be cautious and use conservatism accounting in making financial report, so that book tax differences will not cause company mistakes in giving necessary financial information. According to research conducted by Koubaa and Jarboui (2017), total component 
and component difference in book tax differences in this case have differential implication towards conservatism accounting.

Book tax differences variable partial testing towards tax avoidance, showed that book tax differences variable significantly influences tax avoidance. This research supports research conducted by Jackson (2009); Blaylock, Shevlin, and Wilson (2012); Guenther et al. (2014); and Hanlon and Heitzman (2010) which showed that tax avoidance committed by corporations by applying book tax differences do not violate policies and laws.

Next partial test is conservatism accounting variable test towards tax avoidance. The result shows that conservatism accounting variable does not influence tax avoidance. This research is in accordance with previous research conducted by Watts (2003) and George A. Plesko (2004) which found that the presence of conservatism accounting or caution principle in financial report making is not the reason behind tax avoidance committed by companies. The research conducted by Asgari and Behpouri (2014) also showed that there is a significant positive correlation between conservatism accounting and corporation main tax. Company with high tax report adjustment has big motivation to apply conservatism accounting to lower company's tax expense.

The result of conservatism accounting variable indirect test towards tax differences through book tax differences give indirect influence with the result is as much 0.033 or $3.3 \%$. This value is smaller compared with inter-variable direct influence. It means that even though inter-variable indirect influence is small yet it still influential between conservatism accounting towards tax avoidance through book tax differences. The company must implement decent tax planning in order for conservatism accounting principle used not contradicts with the implemented book tax differences or must be in accordance with laws to prevent committing tax avoidance that unregulated by laws or even violating laws.

\section{Conclusion}

It can be concluded that conservatism accounting practice significantly influences book tax difference in making financial report. Second conclusion, conservatism accounting practice does not influence tax avoidance, it means that caution principle does not influence corporation to commit tax avoidance either. Third, book tax differences has significant influence on tax avoidance, it means that the existence of financial report recording's different principle for taxation interest is influential towards the company in committing tax avoidance. Last conclusion, conservatism accounting practice is not influential towards tax avoidance's influence towards book tax differences; it means that book tax differences using caution principle (conservatism accounting) cannot explain tax avoidance practice. Further research might want to develop this research with including other variables such as profitability, leverage, corporate governance, corporate value. Future research is also encouraged to use more research samples with different specifications.

\section{Acknowledgement}

This research has been granted funding from Directorate General of Research and Development Enhancement, Ministry of Research, Technology, and Higher Education of the Republic of Indonesia (No. SP DIPA-042.06.1.4051516/2017 on December, $7^{\text {th }} 2016$ ). Author would like to express gratitude for Region VII Kopertis of East Java, without whom this research wouldn't be possible. 


\section{References}

Abdul Wahab, N. S., \& Holland, K. (2015). The persistence of book-tax differences. British Accounting Review. https://doi.org/10.1016/j.bar.2014.06.002

Annuar, H. A., Salihu, I. A., \& Obid, S. N. S. (2014). Corporate ownership, governance and tax avoidance: an interactive effects. Procedia - Social and Behavioral Sciences. https://doi.org/10.1016/j.sbspro.2014.11.063

Asgari, M. R., \& Behpouri, M. A. (2014). Investigating the effect of tax costs on accounting conservatism: Evidence from Tehran Stock Exchange. Management Science Letters, 4, 5-10. https://doi.org/10.5267/j.msl.2013.12.007

Basu, S., Kothari Mike Barclay, S., Christie, A., Daley, M., Lilien, S., Pearson, N., \& Shevlin, T. (1997). Accounting \& Economids The conservatism principle and the asymmetric timeliness of earnings 1. Journal of Accounting and Economics Basu / Journal of Accounting and Economics, 24(24), 3-37.

Blaylock, B., Shevlin, T., \& Wilson, R. J. (2012). Tax avoidance, large positive temporary booktax differences, and earnings persistence. Accounting Review. https://doi.org/10.2308/accr-10158

Bovi, M. (2005). Book-tax gap. an income horse race. Working Paper No 61, Desember 2005

Dyreng, S. D., Hanlon, M., \& Maydew, E. L. (2010). The effects of executives on corporate tax avoidance. Accounting Review. https://doi.org/10.2308/accr.2010.85.4.1163

Finnerty, C., Merks, P., Petriccione, M., \& Russo, R. (2007). Categorizing international tax Planning. Fundamental of International Tax Planning. IBFD. 66-69

George A. Plesko. (2004). Corporate tax avoidance and the properties of corporate earnings. National Tax Journal, LVII(3)

Givoly, D., \& Hayn, C. (2002). Rising conservatism: implications for financial analysis. Financial Analysts Journal. https://doi.org/10.2469/faj.v58.n1.2510

Guenther, D. A., Guenther, D., Thank, I., Heitzman, S., Williams, B., \& Wilson, R. (2014). Measuring Corporate Tax Avoidance: Effective Tax Rates and Book-Tax Differences. Retrieved from http://ssrn.com/abstract $=2478952$

Hanlon, M. (2005). The persistence and pricing of earnings, accruals, and cash flows when firms have large book-tax differences. The Accountıng Review, 80(1), 137-166

Hanlon, M., \& Heitzman, S. (2010). A review of tax research. Journal of Accounting and Economics. https://doi.org/10.1016/j.jacceco.2010.09.002

Jackson. (2009). Book-Tax Differences and Earnings Growth. Retrieved from https://papers.ssrn.com.

Jackson, J. L., Dezee, K., Douglas, K., \& Shimeall, W. (2005). Introduction to structural equation modeling (path analysis). Precourse PA08. Society of General Internal Medicine (SGIM), Washington, $D C$ Available from Http://www. Sgim. org/userfiles/file/AMHandouts/AM05/handouts/PA08. Pdf, (May), 1-17

Jackson, M. (2015). Book-tax differences and future earnings changes. JATA American Accounting Association, 37(2), 49-73. https://doi.org/10.2308/atax-51164 
Koubaa, R. R., \& Jarboui, A. (2017). Normal, abnormal book-tax differences and accountıng Conservatısm. Aamjaf Asian Academy of Management Journal of Accounting and Finance, 13(131), 113-142. https://doi.org/10.21315/aamjaf2017.13.1.5

Lee, B. B., Vetter, W., \& Williams, M. (2015). Book-tax income differences and major determining factors. Accounting and Finance Research, 4(55), 1927-5986. https://doi.org/10.5430/afr.v4n3p55

Shevlin, T., Urcan, O., \& Vasvari, F. 2013. Corporate tax avoidance and public debt costs. Retrieved from https://www.rotman.utoronto.ca/-/media/Files/Programs-andAreas/Accounting/Shevlin\%20Rotman\% 20Conference.pdf.

Watts, R. L. (2003). Conservatism in Accounting - Part II: Evidence and Research Opportunities. SSRN Electronic Journal. https://doi.org/10.2139/ssrn.438662

Wilson, R. J. (2009). An examination of corporate tax shelter participants. Accounting Review. https://doi.org/10.2308/accr.2009.84.3.969

Wuensch, K. L. (2016). An Introduction to path analysis. Retrieved from http://core.ecu.edu/psyc/wuenschk/MV/SEM/Path.pdf. 